DOI - https://doi.org/10.5965/2316796310202021070

\title{
EVALUATION OFA BRAILLE-BASED COLOUR CODE PROPOSAL FOR PEOPLE WITH VISUAL IMPAIRMENT
}

Bruna Milam Almeida ${ }^{7}$ Roberto Cardoso Freire da Silva ${ }^{2}$ Júlio Cezar Augusto da Silva ${ }^{3}$ Luiza Beck Arigoni ${ }^{4}$ 


\begin{abstract}
People with visual impairment (PVI) are a group that have some sort of visual loss, including individuals with low vision and blindness. As colour is one of the most important elements in transmitting visual information, its lack of access can be configured as an information and communication barrier, which impacts daily routines and social inclusion. The present study evaluates the suitability of a braille-based colour code proposal for PVI called Universal Colour Code (UCC). Based on user experience methods, exploratory interviews, free association of words, effectiveness tests, and assessment of code were conducted. The results show that UCC has potential for PVI who master braille.
\end{abstract}

Key-words: Colours; Braille; People with visual impairment; User experience; Qualitative research.

${ }^{1}$ bruna.milam@gmail.com

2 rcardosofreire@gmail.com

3 julio.silva@int.gov.br

4luizaarigoni@hotmail.com 


\section{INTRODUCTION}

People with visual impairment (PVI) are a group that have some sort of visual loss, which includes individuals with low vision and blindness. They are at least 2.2 billion individuals worldwide (WHO, 2019) and nearly 7 million people in Brazil (IBGE, 2021). These people face daily several information and communication barriers that affect their autonomy and independence, since many of the contents circulating in social, educational, and professional contexts are presented in a visual way.

Colour is one of the most important elements in transmitting visual information. Through colours, information data can be classified and grouped, meanings are assigned to objects, links with memories and previous experiences are made, and people can communicate with the social and physical environment in which they live (IIDA \& BUARQUE, 2016). The attribution of meanings for the colours is a result of the relationships and experiences undergone by different subjects (BIANCHI et al., 2016; VYGOTSKY, 2001; 2007). The perception of colours is the result of several factors. The first one is the electromagnetic radiation reflected by the object that stimulates retinal photoreceptors from the eye of the observer. Then, occurs the stimulus elaboration at different levels of the visual system, and finally the cognitive elaboration (VIGGIANO, 2011).

The lack of access to colour information can be configured as an information and communication barrier, which impacts in daily activities performance and social participation. Colours are used as a warning for dangerous situations that can harm those who cannot access the information. They are present in daily personal routines, in social interactions and in self-care activities. Colours are involved in product choices for personal presentation, such as clothes and make-up, that can potentially reflect in identity issues, such as self-esteem and social inclusion, including art appreciation (CHO et al., 2020; CHO, 2021; JABBAR et al., 2021) and many other basic situations. They are also part of the educational context as some knowledge is represented and communicated by means of colours (ARAÚJO et al., 2020; BIANCHI et al., 2016; CAMARGO et al., 2008; CAMARGO, 2012). Thus, giving access to colour information for PVIs means to contribute for Sustainable Development Goals (SDGs) proposed by the United Nations (UN), such as reducing inequalities (SDG 10), ensuring quality education (SDG 4), and consequently promoting decent work for all (SDG 8) (UN, 2015).

Braille is a universally recognized system of writing, created in 1824 by the Frenchman Louis Jean-Philippe Braille, and used to translate visual information into tactile information. As a standardised tactile encoding (ABNT, 2015), each of its cells allow up to 63 combinations of raised dots. There are standard dimensions for the diameters of the dots, spaces between the dots and between cells so that tactile information is legible. This implies that texts in braille are about four times longer than the same content written in ink (COOK \& POLGAR, 2008), and represent a challenge in the availability of information in small media such as product packaging and labels (SCHNEIDER et al., 2017).

Initially developed to code letters and signs of the alphabet, later the Braille System also established codifications for numbers and mathematical symbols, musical notes, as well as rules for representing chemical elements (figure 1). Despite this, it still lacks a standardized representation of colours. This represents the need to write the colour names in full. 
Figure 1 Latin alphabet letters and numbers represented in the Braille System.

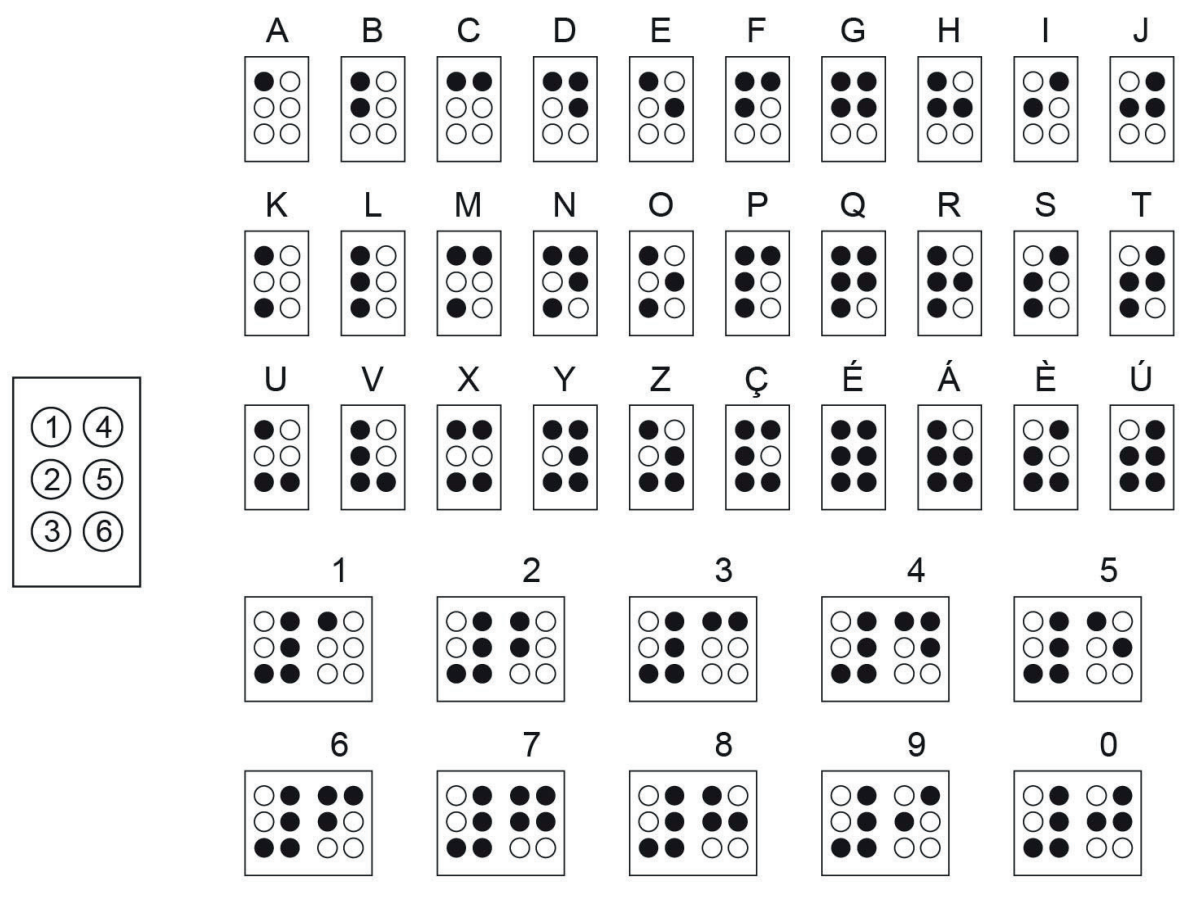

With the challenge of representing colours in a schematic way that can be quickly assimilated by $\mathrm{PVI}$, some tactile colour coding proposals arose, such as See Colour (MARCHI, 2019), Feelipa Colour Code (PIRES, 2011; 2017), and Colorado (NEIVA, 2017). All of them are based on combinations of geometric figures in relief for the representation of primary, secondary, and different colours (IAMAGUTI et al., 2018). Based on the dot structure of the braille cell, it was proposed the Universal Colour Code (UCC) (PEREIRA \& FERRONATO, 2019). Because it uses the cell as support, the UCC can be printed using already existing and widespread tools, such as braille printers and manual writing tools. Moreover, it employs tactile reading skills already developed by PVI and taught at schools.

In this context, the Secretaria de Inclusão Social do Ministério da Ciência, Tecnologia e Inovação (SETAP/MCTI)' (Department of Social Inclusion of the Ministry of Science, Technology, and Innovation from Brazil), commissioned applied research on the UCC designed by Pereira \& Ferronato (2019). The present study evaluates the suitability of this coding system by addressing the following questions:

1. Is it understandable by PVI?

2. Does it meet the needs of the PVI for colour pickup and communication?

3. In what contexts and in what form should it be applied?

The purpose of this paper is to present the first developments of UCC's evaluation of suitability, based on user experience research methods. Next, the methodological procedure is introduced in detail. In addition, we present the results obtained along with a discussion based on the qualitative data collected. At the end, suggestions of further work are made. 


\section{BRAILLE-BASED COLOUR CODE PROPOSAL}

The UCC represents colours using as an organizing principle the physical foundations of primary colour combination to obtain the other shades. The UCC uses the subtractive colour system ${ }^{2}$, but according to the RYB model, with red, yellow, and blue as primary colours. This model, although not as precise as the CMY, producing more charged tones and less range of nuances, is widely used in fine arts and education. It has been spread by painters throughout history due to the low availability of magenta and cyan pigments and is commonly used until today (FRASER \& BANKS, 2007).

In the studied code, the three primary colours are represented in the three lines of the braille cell: points 1 and 4 represent yellow, points 2 and 5 represent red and points 3 and 6 represent blue. The two columns of the braille cell allow the representation of four levels $(0 \%, 33.3 \%, 66.6 \%$ and $100 \%)$ of each of the three primary colours, allowing the representation of up to 64 colours (figure 2). The UCC also foresees the possibility of adding a third column to the matrix, in a variation of the standard cell, extending to eight levels of saturation $(0 \%, 14.3 \%, 28.6 \%, 42.9 \%, 57.1 \%, 71.4 \%, 85.7 \%$ and $100 \%)$ and to 512 representable colours. This three-column version, however, no longer configures the standard braille cell. To indicate the beginning of the colour representation, the UCC has a preceding code represented by points $1,2,3,4$ and 6 , which is equivalent to the representation of the letter "Ç" in the Latin braille alphabet.

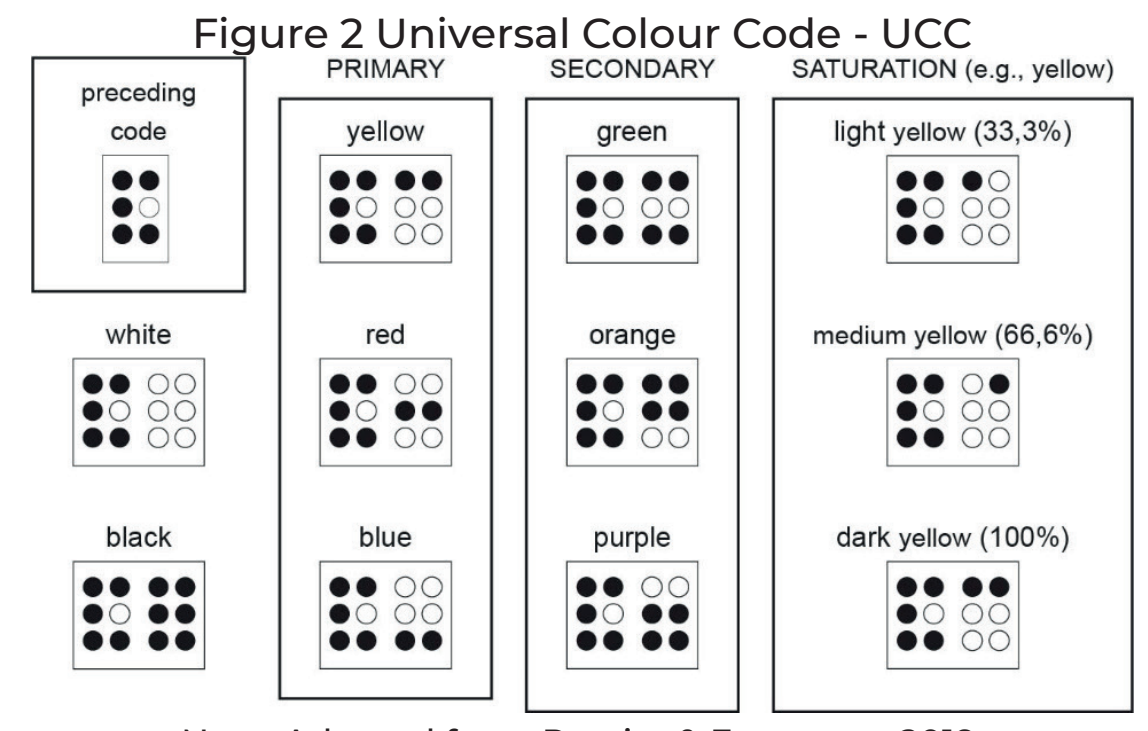

Note: Adapted from Pereira \& Ferronato, 2019.

\footnotetext{
${ }^{2}$ Two colour systems stand out as the most used and precise, the additive and the subtractive systems (PEDROSA, 2010). The additive system deals with the colour emitted by light and uses red, green and blue (RGB) as primary colours. The sum of these three colours at maximum saturation generates white, and their absence, black. The subtractive system treats colour as light reflected by the surface, i.e., the colour of paints and pigments. It has as an example the CMY model (cyan, magenta and yellow) and, unlike the previous system, it generates black in its sum and white in its absence.
} 


\section{METHODOLOGY}

The research aimed to conduct a first evaluation of the UCC, whose hypothesis tested is that the studied code is an effective colour identification resource for PVI with braille mastery. The research was divided into six stages: (1) preliminary investigations, (2) method development, (3) participant recruitment and selection, (4) preparation of the participants, (5) effectiveness tests and (6) assessment of the code (table 1).

Table 1 Research stages and methods.

\begin{tabular}{l|ll}
\hline $\begin{array}{l}\text { 1. Preliminary investiga- } \\
\text { tions }\end{array}$ & Review of literature $\quad$ Exploratory interviews \\
\hline $\begin{array}{l}\text { 2. Method development } \\
\text { ment }\end{array}$ & $\begin{array}{l}\text { UCC course develop- } \\
\text { Definition of data col- } \\
\text { lection protocols }\end{array} \quad$ Committee approval \\
\hline $\begin{array}{l}\text { 3. Participant recruit- } \\
\text { ment and selection }\end{array}$ & $\begin{array}{l}\text { Informed Consent } \\
\text { Form (ICF) signature }\end{array}$ \\
\hline $\begin{array}{l}\text { 4. Preparation of the par- } \\
\text { ticipants }\end{array}$ & $\begin{array}{l}\text { Free association of } \\
\text { words }\end{array}$ \\
\hline $\begin{array}{l}\text { 5. Effectiveness tests } \\
\text { 6. Assessment of the } \\
\text { code }\end{array}$ & $\begin{array}{l}\text { Individual assess- } \\
\text { ment: satisfaction } \\
\text { scale }\end{array}$ & $\begin{array}{l}\text { Collective assess- } \\
\text { ment: focus group }\end{array}$ \\
\hline
\end{tabular}

During the preliminary investigations, it was accomplished a review of literature on the Braille System (composition, teaching and reading) and on the relations of PVIs with colours. In addition, exploratory interviews were conducted with six teachers from the Benjamin Constant Institute (IBC), from different departments and disciplines, to investigate colour pickup and communication for PVI and its relation to learning environment. The information collected served as a basis for the development of the method, especially regarding the stage of preparation of the participants.

At the method development stage, a course was designed with the aim to present the UCC to the participants. Qualitative data collection protocols were defined, as well as the sequence of tasks to be performed during the tests. Tests of the designed procedures were also carried out for a first evaluation of the sequence, as well as training and definition of the roles to be played by the team to minimize risks related to the research with the sample of participants.

The recruitment and selection of participants was done together with the IBC, a national reference centre in visual impairment, where the preparation of the participants, effectiveness tests and assessment of the code were also carried out. The research project has been submitted for approval to the Research Ethics Committee of Faculdade de Medicina de Valença (CEP-FMV) (Valença School of Medicine). An informed consent form (ICF) also had been prepared in braille so that participants could read it autonomously.

The field study took place over a 2-day period in September 2019. On the first day, 
the stage of preparation of the participants was carried out. On the second day, we conducted the effectiveness tests and assessment of the code.

During research planning, the UCC was treated as a colour representation code still under development. The code had not yet been tested and the first test foresaw the identification and evaluation of problems that might lead to the first recommendations for improvements. In this sense, according to the guidelines of Tullis \& Albert (2008), the tests were conducted as a formative kind of test which, by nature, favours qualitative treatment. For this reason, the small number of participants in this study is justified.

Moreover, for the present study, it was defined the use of the two-column code model of UCC, as previously shown on figure 2, because it follows the traditional braille cell format, which participants and other braille readers are already familiar with. Furthermore, it was considered a possible obstacle in identifying and verbalizing shades with a degree of subtlety, since a system with 512 colours allows representing, for example, up to 16 different shades of purple between absolute red and absolute blue, but there are not 16 standard names to designate these shades.

\subsection{Profile of participants}

For the research, individuals working in the Braille Press Division of the IBC were recruited. Participation was defined based on criteria of availability, interest, and mastery of braille. Thus, participants who could not take part of both two days of the research were excluded from the sample. The adoption of a group with high braille reading ability was intended to reduce the risk of reading errors in the tests, which could mask the research result if attributed to errors in understanding the code.

Ten participants aged between 20 and 38 years took part of the study, five females and three males. In terms of occupations, nine were braille proof-readers and one was a bookbinder. All participants declared that they were blind, so the survey did not have any participants with low vision. From the universe of participants, six declared to have visual memory and two declared to perceive colours. In addition, six participants declared to have congenital visual impairment and three declared to have acquired visual impairment. It is important to note that this information on the visual impairment of each participant was based on self-declaration, with the intention of presenting the variety of profiles tested (table 2). 
Table 2 Profile of survey participants.

\begin{tabular}{ccccccc}
\hline Participant & Age & Gender & Occupation & Type of disability * & Visual memory * & Colour Perception * $^{*}$ \\
\hline P1 & 38 & M & Proof-reader & Acquired blindness & Yes & No \\
P2 & 25 & F & Proof-reader & Congenital blindness & Yes & No \\
P3 & 35 & M & Proof-reader & Acquired blindness & Yes & Yes \\
P4 & 21 & F & Proof-reader & Congenital blindness & No & No \\
P5 & 27 & F & Proof-reader & Congenital blindness & Yes & Yes \\
P6 & 34 & F & Proof-reader & Congenital blindness & No & No \\
P7 & 35 & F & Proof-reader & Congenital blindness & Yes & No \\
P8 & 32 & F & Proof-reader & Congenital blindness & Yes & No \\
P9 & 32 & M & Bookbinder & Acquired blindness & No & No \\
* Information obtained through self-declaration & & & \\
\hline
\end{tabular}

\subsection{Preparation of participants}

The preparation for the effectiveness test was carried out as a group, during the first day of application of the research, and was composed of two stages: a dynamic group based on the free association of words technique (MERTEN, 1992), followed by a brief course for presentation of the UCC.

The group dynamic was thought of as a strategy to relax and stimulate participants' sense of autonomy in relation to the survey, with the aim of minimising risks of stress, embarrassment and/or changes in self-esteem, which can be "provoked by the evocation of memories or by reinforcements in the awareness of a restrictive physical or psychological condition" (CEPSH-UFSC, 2015). It also intended to bring out the mental representations related to colours, with the aim of facilitating the learning of the code, through the associations of colours with the meanings attributed by the participants themselves.

Throughout the dynamic, lasting approximately ten minutes, the researchers asked the participants to say out loud one word or expression that came to their mind for each word stated. In order of mention, the words covered were colours, blue, yellow, red, grey, black, white, green, orange, purple, magenta, lilac, light and dark. Since it was a group dynamic, where several people spoke at the same time, it was not possible to identify the authors of all the lines. Nevertheless, it was decided not to interfere while the participants were speaking, so that the dynamics flowed as naturally as possible, even if this resulted in the loss of identification of authors.

The UCC was then presented to the participants through a course lasting approximately thirty minutes. In addition to explaining the logic of code, the course was taught in combination with colour training. Thus, based on the subtractive logic (RYB model) used in code formation, the course was conducted using the approach of primary, secondary, and tertiary colours and colour mixtures. The concept of colour saturation was also approached, by means of the term "intensity", containing three levels: clear, medium, and strong, the latter being equivalent to total colour saturation. In addition, still according to the pigment colour concept, black and white were approached. 
To help guide the course, a braille workbook was developed and distributed to all participants, with the systematized content and fixation exercises. All the contents of the workbook were read together with the group during the course.

\subsection{Effectiveness tests}

The effectiveness tests were designed based on qualitative methods of user experience research. As recommended by Tullis \& Albert (2008), the performance metrics of the analysed code were the success of the task.

The task was the identification of the colours represented through the UCC. In relation to the success of the task, the method of three levels of success was used: total hit, partial hit, and error. The name of the colour and its due saturation (clear, medium, or strong) were considered as total hit. Furthermore, knowing that the theory of colour formation is not a common knowledge for all PVI and considering that what is being tested is the understanding of the code, not the understanding of the logic of colour formation, some additional definitions were made. When dealing with a secondary or tertiary colour, not only the identification of the name of the colour resulting from the mixture of primary colours with their due saturation was considered as the correct answer, but also the name of the primary colours that form the colour, identifying each of the respective saturations. For example, the answer "strong yellow with strong blue" was also considered as the total correct answer for the identification of the strong green colour, since green is a secondary colour resulting from the addition of yellow and blue (table 3).

Following this logic, it was considered as a partial correctness when the identification of the colour - or the primary colours that form it - was correct, but the saturation was wrong. And as an error, when the colour - or the primary colours that form it - was wrongly identified.

Table 3 Three levels of success method example: 'strong green' colour.

\begin{tabular}{ccc}
\hline Full Hit & Partial Hit & Error \\
\hline Strong green & Medium green & Medium purple \\
Strong yellow and strong blue & Strong yellow and strong red & Strong purple \\
& Strong red and strong blue & Strong red and strong orange \\
\hline
\end{tabular}

The test was carried out individually, in random order, on the day following the preparation of the participants. Before the tests, a brief review of the content was made, lasting about ten minutes, as a reminder of learning the code. As a way of minimizing a possible nervousness on the part of the participants, at the beginning of each test the information was reinforced that it was not a test of knowledge, but that it was a test of the effectiveness of the code. Each participant was called individually and given a braille printed sheet containing a statement, followed by a ten-colour sequence.

The colour sequence of the test was systematised to present them different degrees of difficulty without creating a perceptible pattern of increasing or decreasing complexity, aiming to avoid the creation of a reading logic (e.g., primary colours 
followed by secondary, and then tertiary colours). The colours represented in the test are treated here as questions and represented by the letter $\mathrm{Q}$. The sequence included the repetition of two colours (Q1 and Q2), as a form to check the understanding of the information during the test and to mitigate possible initial nervousness.

Table 4 details the questions in order of presentation in the test, as well as the classification of the colours for the training and the degree of difficulty presented by each one. This degree of difficulty has been defined based on the complexity of colour formation from the primary colours of the RYB model, which follows the logic of the code, according to the progression presented during the course. The questions with the highest degree of difficulty have been inserted in the central portion of the test.

Thus, the primary colours (red, yellow, and blue) with total saturation were assigned grade 1; the primary colours with reduced saturation (light or medium) were assigned grade 2; the secondary colours (mixture of two primary colours) with total saturation were assigned grade 3; and finally, the tertiary colours (mixture of two different saturation primary colours) were assigned grade 4. White (absence of colour) and black (sum of all colours) were also assigned a grade of difficulty 1. Following this logic, grey being the equivalent of black with reduced saturation, this one was assigned grade 2 , the same as the primary colours with reduced saturation.

Table 4 Effectiveness test questions, sorted by type and degree of difficulty in colour formation

\begin{tabular}{|c|c|c|c|}
\hline Question & Colour & Classification & $\begin{array}{c}\text { Level of } \\
\text { difficulty }\end{array}$ \\
\hline Q01 & $\begin{array}{c}\text { strong } \\
\text { green }\end{array}$ & $\begin{array}{c}\text { secondary colour with } \\
\text { total saturation }\end{array}$ & 3 \\
\hline Q02 & light red & $\begin{array}{c}\text { primary colour with } \\
\text { reduced saturation }\end{array}$ & 2 \\
\hline Q03 & white & absence of colour & 1 \\
\hline Q04 & $\begin{array}{c}\text { reddish pur- } \\
\text { ple }\end{array}$ & tertiary colour & 4 \\
\hline Q05 & $\begin{array}{c}\text { medium } \\
\text { blue }\end{array}$ & $\begin{array}{c}\text { primary colour with } \\
\text { reduced saturation }\end{array}$ & 2 \\
\hline Q06 & $\begin{array}{c}\text { yellowish } \\
\text { orange }\end{array}$ & tertiary colour & 4 \\
\hline Q07 & black & sum of all colours & 1 \\
\hline Q08 & $\begin{array}{c}\text { strong } \\
\text { green }\end{array}$ & $\begin{array}{c}\text { secondary colour with } \\
\text { total saturation }\end{array}$ & 3 \\
\hline Q09 & light grey & $\begin{array}{c}\text { black with reduced } \\
\text { saturation }\end{array}$ & 2 \\
\hline Q10 & light red & $\begin{array}{c}\text { primary colour with } \\
\text { reduced saturation }\end{array}$ & 2 \\
\hline
\end{tabular}

\subsection{Assessment of the code}

With the purpose of obtaining assessments from participants regarding the UCC, as self-reported metrics of satisfaction, qualitative methods of individual and group application were used during the research. During the group preparation of the partici- 
pants, audio-visual recordings were made to collect perceptions and comments exposed by the participants in relation to the code presented, for further qualitative analysis. Immediately after the tests, to measure participants' satisfaction with the code, the satisfaction scale was applied individually. Based on the SUS (System Usability Scale) technique developed by John Brooke (1986, apud TULLIS \& ALBERT, 2008), it consists of a form with ten statements to be evaluated by the study participants (table 5).

The satisfaction scale was applied orally, with the sentences being read to the participants, who each replied immediately from the numerical scale or using the related semantic expressions. These expressions were presented to the participants prior to the reading of the sentences, being: 1 - I totally disagree, 2 - I partially disagree, 3 - I neither agree nor disagree, 4 - I partially agree, 5 - I totally agree. Audio-visual recordings were made for conference in case of inconsistency of data.

Table 5 Satisfaction scale statements.

\begin{tabular}{l|l}
\hline Statement & Wording \\
\hline 1. I think that I would like to use this colour code frequently. & positive \\
2. I found this colour code unnecessarily complex. & negative \\
3. I thought this colour code was easy to use. & positive \\
4. I think I would need the support to be able to use this colour code. & negative \\
5. I found the composition of this colour code with Braille cells well integrated/ & positive \\
6. I thought this colour code was illogical/inconsistent & negative \\
7. I would imagine that most people would learn to use this colour code \\
very quickly.
\end{tabular}

The choice to apply it in a spoken way was made when considering the complexity of producing this type of material in braille, as well as the understanding that orality could make the participant's experience more natural, like a conversation. In addition, the oral application also allowed the collection of qualitative data from the comments made during the participants' response. On the other hand, the possibility of social desirability bias was considered for the analysis (NANCARROW \& BRACE, 2000 apud TULLIS \& ALBERT, 2008), where orally self-reported data in front of the researcher tends to result in more positive evaluations than if they were done anonymously and in writing, as respondents tend to give answers they believe will please. 
At the end of the test, the participants were brought together again to apply the focus group. Based on a previously prepared question guide, the dynamic took approximately 18 minutes and generated qualitative data in relation to the evaluation of the code. With the help of material from audio-visual recordings, the focus group data were transcribed and added to those from the participants' preparation and effectiveness tests. The interpretation of the qualitative data was carried out together: reports from an individual application technique were supplemented by data from the group techniques.

The method used for the analysis of content was based on the theoretical codification proposed by Glaser \& Strauss (1967 apud FLICK, 2009), where from the transcribed text, open codification and selective codification were applied. As a result, it was possible to identify possible applications and limitations of the proposed code.

\section{RESULTS AND DISCUSSION}

Next, we present the results coming from the exploratory interviews, the free association of words technique, the hits of the effectiveness tests, and the individual and collective assessment. The results, along with the discussion of the findings, are organised in four categories: code evaluation, colours and education, colours meanings and communication in daily routines and Braille System.

\subsection{Code evaluation}

The hits from the effectiveness tests ranged from 75 to $100 \%$, with an average of $87 \%$. It is important to consider that all participants have a good command of braille, since they work in the Braille Press of the IBC. Therefore, in relation to the results presented by the research, it is possible to infer that people with good command of braille, among congenital and acquired blind people, did not present difficulties in reading and identifying the code.

Considering the different degrees of difficulty previously shown on table 4, it was possible to make an analysis by question of the hit rate (graphic 1). Thus, the questions with degree 1 of difficulty, Q3 (strong green - secondary colour with total saturation) and Q7 (white - absence of colour), were 100\% hit by the nine participants. Questions Q4 (reddish purple - tertiary colour) and Q6 (yellowish orange - tertiary colour) belonging to grade 4, being the highest grade in difficulty, had hit rates of $56 \%$ and $44 \%$ respectively. This means that in the case of Q4, five participants had a total hit, two participants had a partial hit, and two participants made a mistake. In Q6 there were four participants with total hit, two with partial hit and three errors.

Question Q5 (grade 2: medium blue - primary colour with reduced saturation) was also 100\% correct. Questions Q01 and Q08 (strong green - secondary colour with total saturation), although categorised with the same grade and being the same colour repeated, had a partial hit from the same participant, leading to a hit rate of $89 \%$. 
Graphic 1: Percent of hits by questions in the effectiveness test charts.

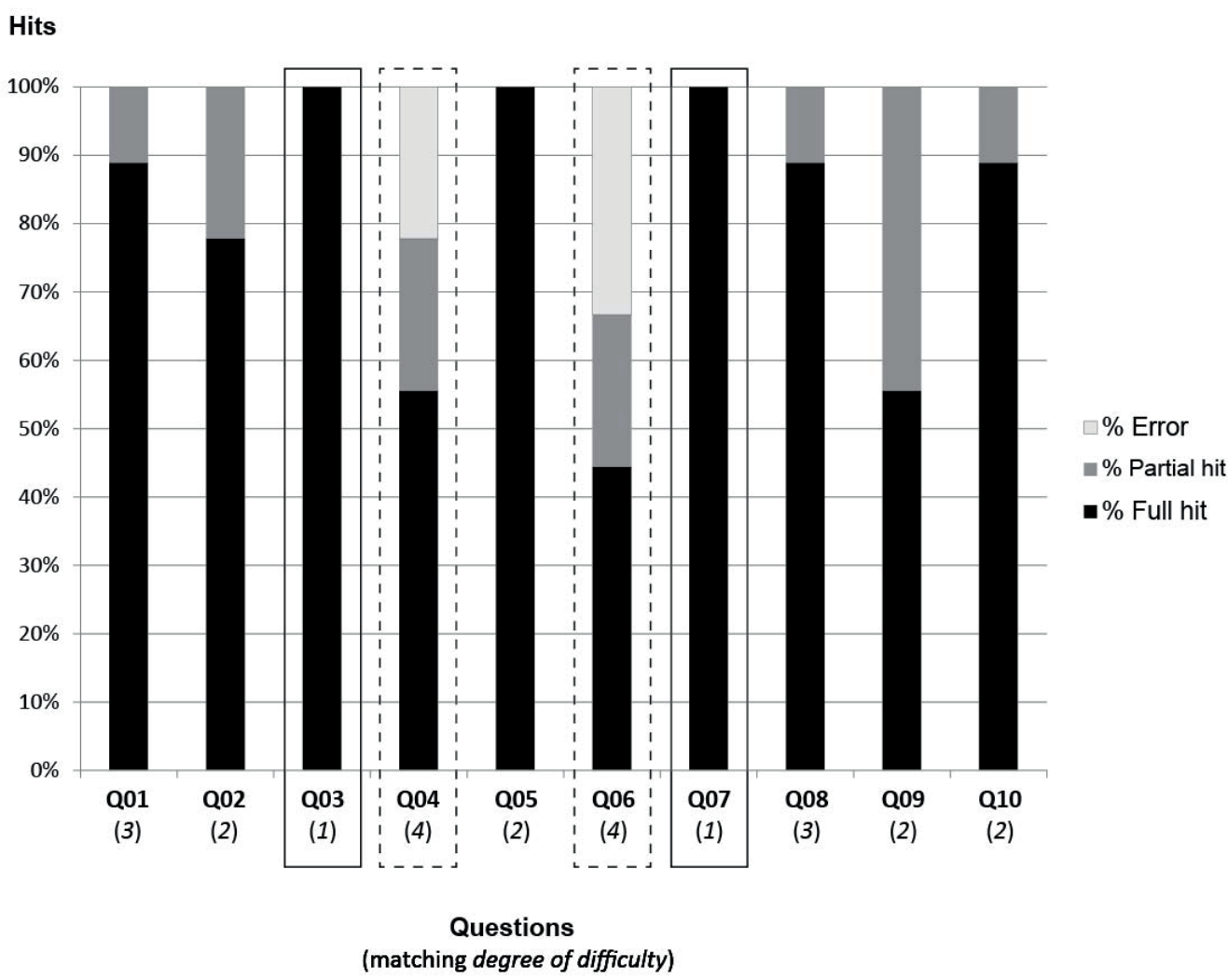

The result confirmed the expectations: the questions categorised by the researchers as less difficult had a higher hit rate, while those with a higher degree of difficulty had a lower hit rate. Therefore, the difficulty on the identification of the colours by using the UCC happened according to the degrees of difficulty of the formation of colours. That means that the difficulty found by the PVIs is compatible to the difficulty that we can find on the seers. As UCC is based on braille and considering that the participants have high braille reading ability, it is possible to assert that this characteristic of the proposed code contributed to not generate difficulties beyond the ones that is normally faced by seers regarding colour theory. With the intention of giving more assertiveness to this finding, future studies about learning colour formation and involving the comparison of seers and PVIs can be made.

Regarding the satisfaction, the individual assessment by participants varied between 60 and 85 points (graphic 2). The overall average evaluation of the nine participants from the satisfaction scale was 77.8. 
Graphic 2: Chart of satisfaction assessment

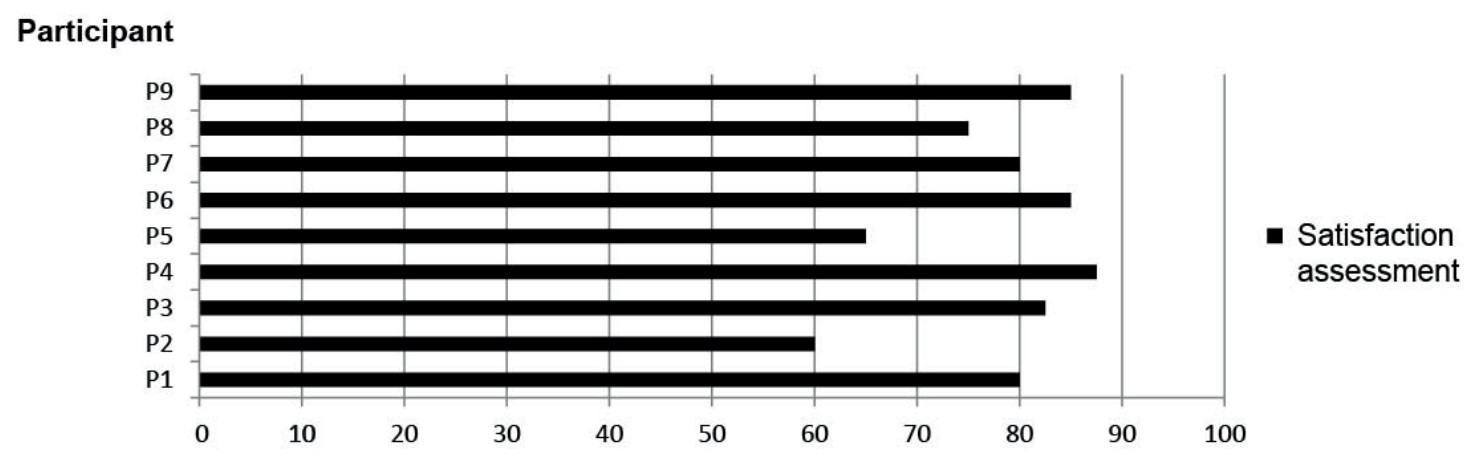

Considering the average hits per participant in percentage form, it was possible to compare the assessment grades according to the satisfaction scale and the average hits of each participant, considering a scale from 1 to 100, as shown in the graph below (graphic 3). Despite the social desirability bias mentioned above (NANCARROW \& BRACE, 2000 apud TULLIS \& ALBERT, 2008), it is possible to note a coherence between the assessments and the percentage of hits. We can note two deviations concerning participants 1 and 4, who had satisfaction ratings slightly higher than the hits, which may suggest that the bias did in fact occur.

It is possible to infer that, in general, the participants assessed the UCC positively. Also, the satisfaction assessment occurred proportionally to their performance and according to the percentage of hits. Hence, considering the metrics collected of effectiveness and satisfaction, the preliminary evaluation of the code indicates a positive result, meaning that the UCC has potential for understanding by PVI who master braille. So, further studies about the UCC with a larger population to allow an analysis of the different PVI profiles are required to deepen the understanding and increase certainty.

Graphic 3 Comparative chart of satisfaction assessment versus average hits Scale

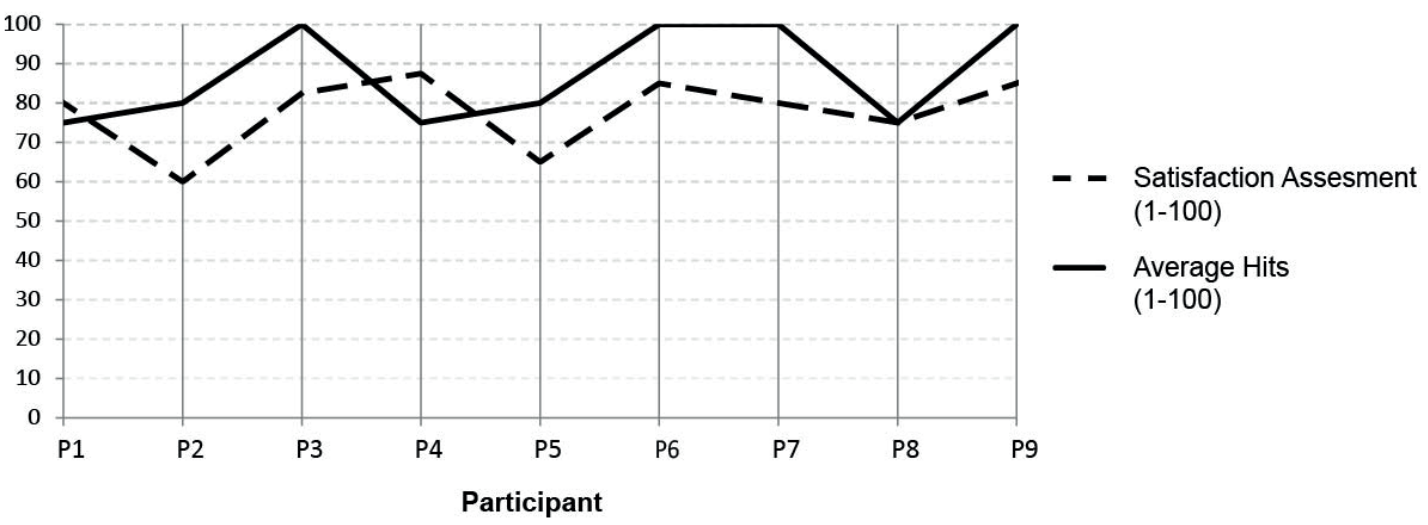




\subsection{Colours and education}

During the assessment of the code, a relevant prerequisite of the code was identified: the understanding of colour theory (table 6). It became evident through the participants' speech the importance of colour training for the understanding of the code. Some of them reported a lack of knowledge about colour mixing (P2, P3, P5, P6), which they deemed necessary to explain during the course offered the previous day.

Still on colour mixing subject, participants reported the need for time for study and practice to solidify learning. In this respect, it should be noted that the hiatus between the presentation of the code to participants and their evaluation was only one day. Moreover, such placement is expected if we consider that the mixing of colours is a semantic association created by them from the learning of the code, being usually performed by seers in a way associated with visual stimulus, since access to the visual characteristic of colour is dependent on visual observation (CAMARGO et al., 2008)

Therefore, the participants declared that there is a lack of adequate teaching of colour theory in their own school training, which justifies the lack of understanding about the mixing of colours. The participants highlighted personal experiences and reports from PVI friends, which indicate that there is no uniformity on how colour teaching is done for people with visual impairment, considering different institutions, different teachers, and the individualities of each student. Thus, they reported that, for them - as adults who master braille - the difficulty of code lies in the knowledge and understanding of colour training.

However, the teachers interviewed reported that, in relation to the teaching of colours at more advanced ages, the institute has recently started to offer professional technical education at a secondary level, including the course in handicrafts. One of the compulsory subjects of the course is Painting and Colour Theory. According to the teacher of this subject, most students have low vision and already come with a previous knowledge of colours, acquired during regular school education. Generally, they already know how to identify primary and secondary colours, but the concept of complementary colours remains to be taught. Besides this, other subjects taught in the technical courses have as a prerequisite the understanding of the basic concepts of colours, as also shown by Camargo (2012) in his studies on teaching knowledge for inclusion students with visual impairment in Physics classes.

Teachers use materials developed especially for PVI, which try to translate concepts associated with colours in a tactile way. In the physics discipline, the material developed to teach concepts of light related to the electromagnetic spectrum includes a caption that relates colours and textures, represented in a tactile spectrum. In the discipline of Painting and Colour Theory, the colour circle is also represented in a tactile way with the aid of a caption. In addition, consecrated works are translated into tactile patterns, as in the case of the work of Piet Mondrian.

Therefore, although there are studies and propositions of multi-sensory experiences for colour recognition, such as applying sounds, temperature, or scents (CHO, 2021), the most accepted approach to the colour challenge is the use of tactile colour patterns (TCP), as also proposed by Cho et al. (2020) for art appreciation and by Araújo et al. (2020) for the representation isarithmic maps of temperature, commonly used in Geography discipline. Also, Jabbar et al. (2021) present a wearable assistive technology for visual impairment aiming a tactile colour translation for artwork. 
Although tactile adaptations, such as the reproduction in relief of visual content, allow the communication of some information from the books to PVI, it is known that some meanings are inseparable from vision, i.e., mental representation depends on a certain sensory perception (CAMARGO et al., 2008). Thus, the understanding of visual characteristics such as transparent, opaque, and translucent, as well as phenomena of reflection and refraction of light contained in disciplines such as Physics, presents a great challenge for people with visual impairment, especially for the congenital blind (CAMARGO, 2012), who understand colours as an abstraction (BUSTOS et al., 2004).

Because of the lack of knowledge on colour formation, participants (P5, P2) raised the need for the teaching of colour theory at school. They mentioned the possible benefit of using a braille-based code for this purpose in current times, where few PVI have knowledge of braille because they rely on technology. For this reason, is reasonable to affirm that the UCC can contribute on two of the SDGs proposed by the UN by ensuring inclusive and equitable quality education as well as promoting lifelong learning opportunities for all (SDG 4) and reducing inequalities within and among countries (SDG 10).

They also stated that, in general, the learning of colours for blind people takes place through social coexistence. This statement corroborates what was observed by Vygotsky (2001) and demonstrated by Bustos et al. (2004), that social and multisensorial aspects influence the formation of meanings, with the aim of giving concreteness to abstract themes.

Table 6 'Colour and education' themed transcripts.

Statements - Speech transcription
"That foundation given yesterday helped a lot. (...) Explaining that yellow with blue gives green. Because a per-
son who has no sense of it would not get it. They wouldn't get it and just by putting his hand in the code, they
would never get to a bluish green"

“This is basic information for you to do all the rest, but if you don't have it, you don't get anywhere (...) I didn't have this notion of primary colours, secondary colours, so that you could get there and form a colour"

"At first, I had a bit of trouble, but then I got cool. And the mixing part is a bit more complicated (...) It's a matter of really studying, of understanding!"

"At first it was a bit [difficult], right? (...) Of course when you make the mixtures, right? You have to study a little more, but you can get it easily."

"We studied in a school specializing in visual impairment (...) We had contact with many other things, including textures, with geometric shapes, but the question of colour was not taught. (...) For example, I know some people who studied in regular schools, even blind from birth, who studied in regular schools, where the teacher took the time to explain it. But then it was about the teacher, it was about that school, which took the time and explained about primary, secondary, tertiary colours, about warm colours, cold colours. It's not the code... it's prior knowledge."

"I only went to art class in high school (...) This whole part I missed, because you can't do it! So, it's easier for the teacher to evaluate you by other [things], ah... your presence in class, your attendance, theoretical work..."

"At a time when we are experiencing a very strong 'disbrailisation' of children, right? As a substitute for applications, electronic things (...) it's a question that we need to work on in preschool, right? In the early years, because we who were born blind don't have much notion of mixing colours... what colours we mix with the objective of getting those other colours. Suddenly we learn because of music, or we learn because of someone who speaks to us, but that's not something we see at school."

"I think when we talk about school, in the initial formation of these students, yes! And even the norm, a normalization for colours, that would be very useful. Now for clothes, for utensils I don't believe much." 


\subsection{Colours meanings and communication in daily routines}

According to the teachers interviewed, apart from the existence of various nuances of visual impairment, it is not clear at preschool how much light and colour they can perceive, which can change over time until adulthood. For this reason, the aim is to offer pre-school students as many different stimuli as possible, by means of very colourful pedagogical objects. Also, according to the teachers, at this stage it is common for visually impaired children to refer to colour by using the names of characters and toys, through associations made with their help (e.g., "Jaspion" instead of "red"). The teachers reported that other common associations related to the external environment, such as the yellow sun and the blue sky, are absorbed by the pupils in their social life.

Vygotsky (2001; 2007), a notorious theoretician in the field of education, states that the attribution of meanings is influenced by the relationships and experiences experienced by different subjects, considering everything that exists in our consciousness. As reported by Bianchi et al. (2016), the learning process is multi-sensorial, and the formation of meanings is sociolinguistic. Therefore, the imagery contents formed, as well as the concept of colours, do not depend exclusively on the stimuli received by the receptors of our senses, involving other associations. In this way, the very communication between the subjects only becomes possible in the existence of shared meanings, formed from the intrinsic relationship we establish with the world and from the associations we build through our relationships and from the stimuli received.

Before the presentation of the UCC for the participants, it was possible to collect data regarding the association of words related to colours. The compilation of the associations made by the participants can be seen in table 7 . 
Table 7: Result of the method of free association of words related to colour, with identification of participants.

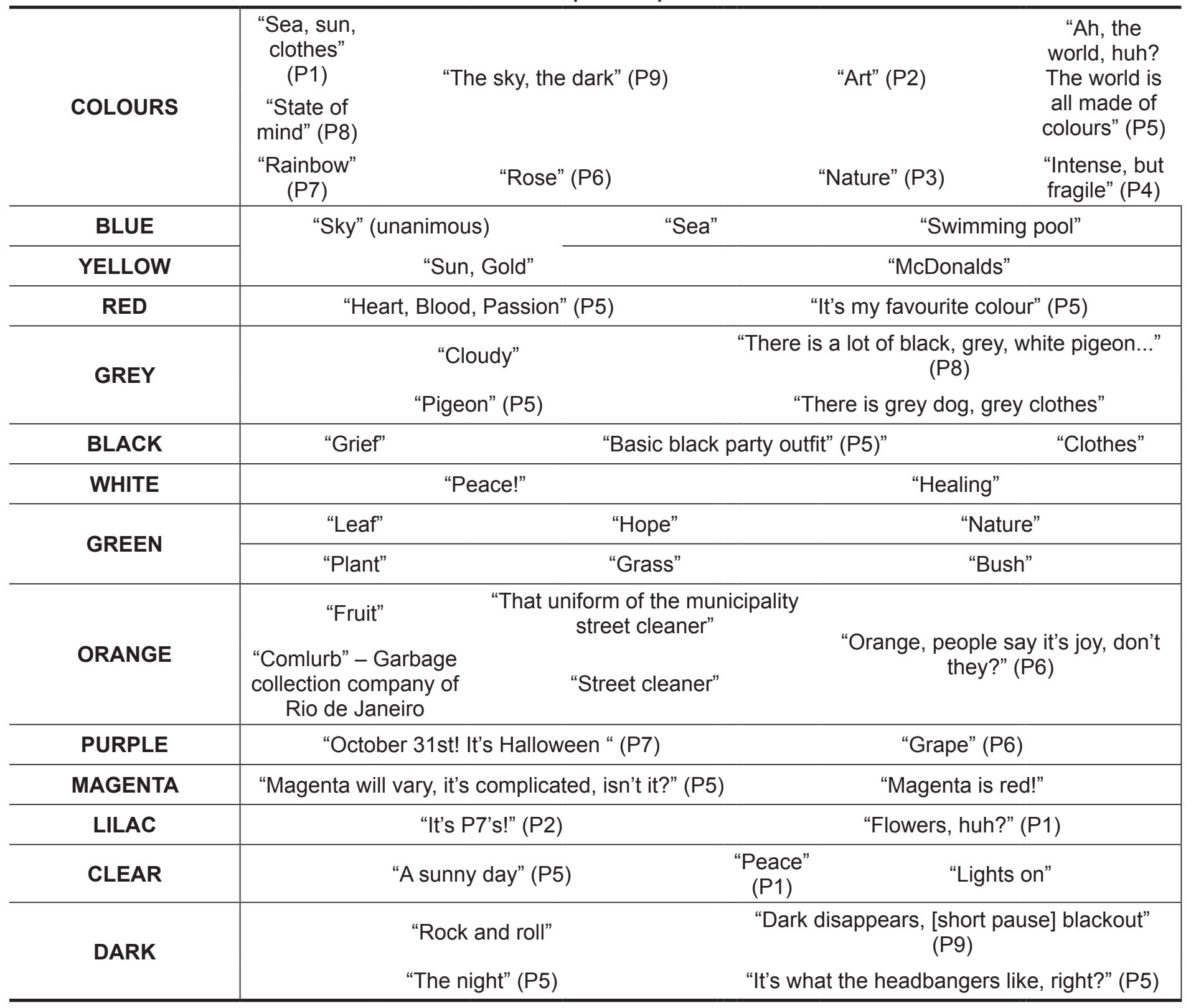

Thus, it was possible to identify that the associations of meanings linked to colours in this dynamic corroborate with what was presented by Bianchi et al. (2016), with similar words and expressions and, in some cases, the same as those presented in the previously mentioned research. Likewise, the results are in line with the study by Bustos et al. (2004), which reports on the importance of learning and past experiences as triggers of these associations. Hence, it is reiterated from this experiment that the formation of meaning related to colours has a great factor of collective cultural construction and of life experiences, these meanings being, for the most part, shared with those of seers in common sense. It is interesting to note that the participant P2 mentions the participant P7 when relating to the lilac colour, indicating her preference for colour.

During the assessment of the code, participants mentioned that the application of colours present in everyday life is of a broader complexity than the representation 
of a pure colour (table 8). It includes prints, patterns, and other visual characteristics of colours such as gloss, matte, metallic and satin. Thus, they reported that code can help to give a more superficial understanding of colour, but that it cannot meet all this complexity that depends on visual observation. Participants also revealed concern about how to relate the colour representation made possible by code - in its logic of colour formation - and the cultural names of colours, popularized through social or even commercial factors.

Participants reported frequent use of smartphone applications for everyday colour identification. They also mentioned the difficulty relative to subjectivity in the perception, identification and naming of colours, besides the taste of each person. The understanding of this subjectivity makes some people resort to the help of sighters in the identification of colours, through the establishment of a relationship of trust, as also pointed out by the work of Schneider et al. (2017).

Additionally, one of the participants (P2) mentioned the application of the code and the learning generated by it as beneficial also for the professional inclusion of PVI in the technology industry. Again, the UCC can contribute for another SDG of the UN by promoting full and productive employment, as well as decent work for all (SDG 8) (UN, 2015), when including PVIs in growing industries.

Table 8 'Colours meanings and communication in daily routines' themed transcripts.

\footnotetext{
Statements - Speech transcription

"I thought it was a really cool idea to explain colour theory. Now, on a day-to-day basis, we have a very large universe that won't fit all of this."
}

Participant

"We have trending colours. This year they call the colour by a name, next year they call it by another. They are colours that we know are regular colours, but people give different names."

"Suddenly you don't have that thing, 'it's a tiffany green', but you know, you'll get a notion that it's a green."

"Because I think some colours have become popular with very specific names like, I don't know, pumpkin colour. (...) The pink itself already has light pink, dark pink, baby pink, shock pink, pink this, pink that ..."

"Of course, we will always slip into subjectivity, right? Because there are people who will see green, there are people who will see blue, although there is a difference not everyone will see. We must think about those subjectivities of people, but since the applications are very rudimentary, then we usually must turn to people. (...) when you're not going to use the app, it's a person you trust."

"When you are with a human being you can also ask what you want to know (...) So when I go to buy some clothes, for example, I usually take someone to go with me, take a close friend with me." 


\subsection{Braille System}

As braille is a pre-requisite of the code, the participants identified a concern about a possible difficulty that might arise with other PVI that do not have the same degree of braille mastery as they do. It is true that only few people with severe visual impairment know how to read in braille. However, one reason for that is that many of them become blind after age 65 (COOK \& POLGAR, 2008). So, the UCC can be a tool for encouraging young PVIs to learn braille, as they learn about colour theory as well.

Also, according to some of the participants, the wide variety of existing colours makes the representation complex and, in their view, may not be fully covered using the Braille System. Although, it is important to point out again that the UCC foresees the addition of one more column to the matrix (totalling three columns), which allows increasing the variety of colours and shades (PEREIRA; FERRONATO, 2019). According to the reasons mentioned above, the code presented to the participants was of only two columns, which may justify such a perception on their part, since they did not know the full potential of the code developed.

Table 9 'Braille System' themed transcripts.

\begin{tabular}{l|l}
\hline Statements - Speech transcription & Participant \\
\hline "I don't know if it is going to be easy to everybody, to all visually impaired people & \\
will have this facility that we are having here (...) I don't know if all visually im- & (P6) \\
paired people will be able to be reached by it" & \\
"There you see those shades and more and more shades appear and then it & \\
becomes endless. Braille is not endless (...) I find it difficult for you to represent & (P3) \\
all the shades of yellow." & \\
"I think it is a lot for the code to cover (...) an outfit that's one colour, one tone, \\
one colour background but has a print. Where will this be written? The code will \\
get too big." & (P2) \\
"Remembering that the child, for example, of early childhood education will not \\
have the slightest notion of these points that we read here. You have to learn \\
braille (...) You don't work [braille] in kindergarten, do you?"
\end{tabular}

\section{CONCLUSIONS AND FURTHER WORK}

The results show that the UCC was understandable to the research population, indicating that the code has potential for understanding by PVI who master braille. Although the UCC is not self-explanatory, a brief prior explanation of the code combined with the teaching of colour theory was sufficient to make the code understandable for the participants. They assimilated the representative logic of the code and were able to verbalize the colour represented under support of the UCC. The difficulty found by the PVIs was compatible to the difficulty normally faced by seers regarding the leaning of colour theory. Results also suggest that the UCC can be understandable for different nuances of visual impairment: congenital or acquired blindness, with or without visual colour memory. 
During the study, PVI correctly captured the representation of primary and secondary colours in support of the UCC. The code, in its simplified two-column form, as presented to participants, constitutes a potential resource for colour representation and communication in general everyday life situations, where 64 colours is a sufficient range to cover the need for representation.

Preliminary research has revealed that PVI already communicate about colours, with each other and with sighters, with the same nomenclature and using the same metaphors, through shared cultural learning or simple verbalism. In this sense, the UCC can contribute to the sense of inclusion and belonging of the PVI in sighters groups, by deepening the understanding of the logic of colour formation. In addition, the code can allow access, through the PVI own language, to information that is today restricted almost exclusively to sighters.

Preliminary results indicate that the UCC also has the potential to make a significant contribution in the educational context. The code has proved to be a possible didactic tool for teaching colour to PVI, especially those without colour memory.

Nevertheless, future research is suggested on the following points:

1. Tests with a larger population to allow an analysis of the different PVI profiles, with different nuances of visual impairment, and different degrees of braille mastery.

2. Investigation of code acquisition in its three-column expanded format, which allows the representation of 512 colours. Situations were raised where there is a need for a greater variety of shades, such as everyday objects, clothing, and make-up.

3. Research on the insertion of the UCC as a tool for teaching colours in school training. On the one hand, it can allow the learning of colour theory in the case of children already literate in braille. On the other hand, it can be presented in advance as a tool to stimulate the learning of braille, with a view to its practical application in everyday life to identify colours.

Finally, the code presents limitations as identified by the participants, considering the individualities and the different ways in which subjects perceive and experience the world. Since colour is only one aspect of a complex set of interdependent visual characteristics, it is understandable that the identification of colour alone is not sufficient to fill the gap of visual information lost with visual impairment. However, as colours contain meanings that go beyond the visual characteristic, by enabling their identification, the UCC can give access to diverse cultural meanings, presenting potential as an inclusion and accessibility resource for PVI.

\section{Acknowledgments}

The researchers thank the Secretaria de Tecnologias Aplicadas do Ministério da Ciência, Tecnologia e Inovação (SETAP/MCTI) (Department of Applied Technologies of the Ministry of Science, Technology, and Innovation from Brazil), the Benjamin Constant Institute (IBC), the Research Ethics Committee of Faculdade de Medicina de Valença (CEP-FMV) (Valença School of Medicine) and the participants for their support in conducting and publishing this research. 


\section{REFERENCES}

ARAÚJO, N. S.; AMORIM, F. R.; ANTUNES, A. P.; MARCHI, S. R.; SCHMIDT, M. A. R.; ANDRADE, A. F.; DELAZARI, L. S. An experiment using the graphic variable colour and the See Colour code on isarithmic maps accessible to blind and normally sighted people. Bulletin of Geodetic Sciences, Curitiba, v. 27, spe ed., 29 Nov. 2020. Available at: https:// doi.org/10.1590/s1982-21702021000100006. Accessed on: October 04, 2021.

ASSOCIAÇÃO BRASILEIRA DE NORMAS TÉCNICAS [ABNT]. NBR 9050: Acessibilidade a edificações, mobiliário, espaços e equipamentos urbanos. Rio de Janeiro. 2015.

BIANCHI, C.; RAMOS, K.; BARBOSA-LIMA, M. C. Conhecer as cores sem nunca tê-las visto. Revista Ensaio Pesquisa em Educação em Ciências. Belo Horizonte, 2016, vol.18, n.1, pp.147-164. ISSN 1415-2150. Available at: https://www.scielo.br/pdf/epec/v18n1/1983-2117-epec-18-01-00147.pdf. Accessed: 03 May,2020.

BUSTOS, C.; FEDRIZZI, B.; GUIMARÃES, L. B. M. Percepção dos deficientes visuais: cores $X$ texturas. Proceedings of 1st Latin American Conference on Sustainable Construction and the 10th National Meeting on Built Environment Technology, São Paulo, July 2004.

CAMARGO, E. P.; NARDI, R.; VERASZTO, V. A comunicação como barreira na inclusão de alunos com deficiência visual em aulas de óptica. Revista Brasileira de Ensino de Física, São Paulo, v. 30, n. 3, p. 3401, 2008.

CAMARGO, E. P. Saberes docentes para a inclusão do aluno com deficiência visual em aulas de física. São Paulo: Editora UNESP, 2012.

CEPSH-UFSC. Orientações para evitar que seu projeto fique em pendência. Florianópolis, 2015. Available at: https://cep.ufsc.br/orientacoes-para-evitar-que-seu-projeto-fique-em-pendencia-3/. Access in: 13 July 2020.

CHO, J. D. A Study of Multi-Sensory Experience and Colour Recognition in Visual Arts Appreciation of People with Visual Impairment. Electronics, [s. I.], v. 10, ed. 4, p. 470, 15 Feb. 2021. Available at: https://doi.org/10.3390/electronics10040470. Accessed: 04 October 2021.

CHO, J. D.; QUERO, L. C.; BARTOLOMÉ, J. I.; LEE, D. W.; OH, U.; LEE, I. Tactile colour pictogram to improve artwork appreciation of people with visual impairments. Colour Research and Application, [s. I.], v. 46, ed. 1, 11 set. 2020. Available at: https://doi.org/10.1002/ col.22567. Accessed: 04 October 2021.

COOK, A.M.; POLGAR, J. M. Cook and Hussey's assistive technologies: principles and practice. 4 ed. Mosby Elsevier, 2008.

FLICK, U. Introdução à pesquisa qualitativa. 3rd ed. Porto Alegre: Artmed, 2009. 
FRASER, T.; BANKS, A. O Guia Completo da Cor. 2nd ed. São Paulo: Editora SENAC.

IAMAGUTI, M.; GADOTTI, M.; HENRIQUES, F.; et al. Analysis of graphic codes for colour representation: ColorADD and Feelipa Colour Code in Portuguese companies. Information Design Journal, v. 24, n. 2, p. 116-130, 2018.

IIDA, I.; BUARQUE, L. Ergonomia: Projeto e produção. São Paulo: Blucher, 2016.

INSTITUTO BRASILEIRO DE GEOGRAFIA E ESTATÍSTICA [IBGE]. PNS 2019: país tem 17,3 milhões de pessoas com algum tipo de deficiência. [S. I.]: Agência IBGE Notícias, 26 ago. 2021. Available at: https://agenciadenoticias.ibge.gov.br/agencia-sala-de-imprensa/2013-agencia-de-noticias/releases/31445-pns-2019-pais-tem-17-3-milhoes-de-pessoas-com-algum-tipo-de-deficiencia. Accessed: 20 October 2021.

JABBAR, M. S.; LEE, C-H.; CHO, J. D. ColorWatch: Colour Perceptual Spatial Tactile Interface for People with Visual Impairments. Electronics, [s. I.], v. 10, ed. 5, p. 596, 4 mar. 2021. Available at: https://doi.org/10.3390/electronics10050596. Accessed on: October $04,2021$.

MARCHI, S. R. Design Universal de Código de Cores Tátil: Contribuição de Acessibilidade para Pessoas com Deficiência Visual. 249 f. Thesis (Doutorado em Engenharia Mecânica) - Programa de Pós-Graduação em Engenharia Mecânica, Universidade Federal do Paraná, Curitiba, 2019.

MERTEN, T. O teste de associação de palavras na psicologia e na psiquiatria: história, método e resultados. Análise Psicológica, Lisbon, v. 4, n. 10, p. 531-541, 1992.

NEIVA, M. Colloradd. Available at: http://www.coloradd.net/. Accessed on: October 02, 2017.

PEDROSA, I. Da cor a cor inexistente. São Paulo: Editora Senac, 2010.

PEREIRA, G. S.; FERRONATO, R. Código tátil de identificação de cores para pessoas com deficiência visual. Application: 26 November 2019.

PIRES, F. N. Feelipa colour code. Available at: http://www.feelipa.com/pt/. Accessed: 02 October 2017.

PIRES, F. N. Fo.co. Master thesis, Product Design, Faculty of Architecture of the Technical University of Lisbon, Lisbon, Portugal. 2011.

SCHNEIDER, J.; FERREIRA, M. G. G.; RAMIREZ, A. R. G.; SANTOS, C. T. Etiquetas têxteis em braile: uma tecnologia assistiva a serviço da interação dos deficientes visuais com a moda e o vestuário. Estudos em Design, Rio de Janeiro, v. 25, ed. 1, p. 65-85, 2017. Available at: https://estudosemdesign.emnuvens.com.br/design/article/view/435. Accessed: 04 October 2021. 
TULLIS, T.; ALBERT, W. Measuring the User Experience: Collecting, Analysing, and Presenting Usability Metrics. 1st ed. Burlington: Morgan Kaufmann, 2008.

UNITED NATIONS [UN]. Transforming our world: The 2030 agenda for sustainable development. United Nations, [s. I.], 2015. Available at: https://sdgs.un.org/publications/ transforming-our-world-2030-agenda-sustainable-development-17981. Accessed: 04 October 2021.

VIGGIANO, M. P. Percezione visiva e cognizione. In: GIANNINI, A. M.; MILANI, M.; VENTURINI, G. Psicologia e Società: Design. Firenze: Giunti Editore S.p.A. 2011

VYGOTSKY, L. S. A formação social da mente, 4th ed. São Paulo: Martins Fontes, 2007.

VYGOTSKY, L. S. Pensamento e linguagem. [S.I] Ed. Ridendo Castigat Mores, 2001.

WORLD HEALTH ORGANIZATION [WHO]. World report on vision. World Health Organization, [s. I.], 2019. Available at: https://www.who.int/publications/i/item/9789241516570. Accessed: 20 October 2021. 